Research, part of a Special Feature on The Recent History and Practice of Local Fisheries in a Globalizing World

\title{
The Life and Times of Snoek
}

\author{
Marieke Norton $^{1}$
}

ABSTRACT. The Cape Snoek, or Thyrsites atun, is a species of fish that has a significant presence in the history of the Western Cape and the development of Cape Town. The snoek is a lively creature that is historically, culturally, economically, and ecologically active in the Western Cape. I argue that in the case of the Cape snoek, the fish and the Cape are performed together; through acts of differentiation, they mutually constitute one another.

Key Words: ecology; economy; history; snoek, Western Cape

\section{INTRODUCTION}

The snoek has no teeth tiny enough

By which to grasp its own condition.

(Coovadia 2012)

In the web of Cape Town's histories, a significant strand is the close relationships that its economics, politics, and people have with the marine environment. This strand is, in fact, so significant that it encompasses a range of stories, which together weave a particular characterization of Cape Town.

To trace this strand, I examine the Cape snoek (Thyrsites atun), a species of fish that has a significant presence in the histories of the western Cape and Cape Town. The snoek is a historical, cultural, economic, and ecological feature of the region. The living, breathing creature that has bred, and continues to breed, feed, and die, is the basis of investigations for a wide range of researchers-historians, marine biologists, fisheries scientists, economists, other social scientists, and consumers. Many discourses and research processes transform that living, knowing creature into an "object-that-is-known;" a given (Mol 2002). To reject this simplicity of approach, in favor of complexity, is to identify the diverse relations that individuals and collectives have had and can have with snoek, and viceversa. Mol discusses the idea that "an object is real...because it is part of a practice" (2002:44). Mol'sinvestigation of enactment leads her to identify the ways in which an object is constituted, through situating it in a complex of activities and interactions, constituting "the body multiple" (Mol 2002:55). In her reasoning, the body multiple is that which is less than one but more than many, hanging together through the strength of its relations (Mol 2002:54-55). In a related paper, Law and Mol (2008) discuss the idea of the "sheep multiple;" however, they emphasize that this multiplicity is not a plurality but a convergence of complex and intricate relations between the versions thereof (2008:65). Here, I will examine the "snoek multiple," that is, the convergence of various localized versions of snoek that come into being, but are neither fixed nor given (Mol 2002:42). Lien and Law (2010), talk about "what counts as 'nature' when icons of wilderness are enrolled in regimes of domestication" (2010:65). Drawing on the icon of the Norwegian salmon, one of their central claims is that "salmon and nature are performed together, through various acts of differentiation that constitute what they both are" (ibid.). I argue that this is equally true for the snoek that swim in this telling: the snoek and the Cape are performed together; through acts of differentiation, they constitute what they both are.

The actions of the fish, and the variant human interpretations thereof, together tell an economic history of the relationships the Cape's denizens have with the city and its marine environment. Interpretations of snoek are often mobilized to perform specific functions. Its alliance with the history, economic activities, racial and class struggles, and cuisine of the Cape allows it to be read as a key to how individuals enact a place. The outlines I sketch below show that, in the various manners in which snoek is enacted, it assembles an intersection of ideas, activities, and emotions that together enact a particular idea of Cape Town. Bennet (2009:ix) addresses modernist propensities to treat creatures as things, not least because such a rationale may be "one of the impediments to the emergence of more ecological and more materially sustainable modes of production and consumption" (ibid.). Hence, to treat snoek as something other than a "thing" is a step toward re-imagining the manner in which we relate to the marine environment. Bennet (2009), Mol (2002), Law and Mol (2008), and Lien and Law (2010) all build on Latour's (1993) ideas about the intertwined nature of the natural and social. In Mol's words (2002:30-31), Latour (1993) seeks a way out of the trap of the "nature-culture" divide by addressing the contradiction between thinking and practice in the modern world. He shows this contradiction to be a clash between "knowledge, as articulated" and "knowledge, as embedded." According to Latour (1993), the reason for this clash is that modern thinking "glorifies" the ability to distinguish between social ("the knowing") and natural ("the known") phenomena. However, as Mol (2002:30-31) observes, Latour does not acknowledge that, in practice, they are mutually constituted 
through their relations and associations. In what follows, I sketch various practices, activities, and characterizations of snoek that enact the creature by combining the social with the ecological.

\section{THE CAPE SNOEK}

Snoek (Thyrsites atun) is a member of the mackerel (Gempylidae) family, found off New Zealand, South Africa and Chile. Snoek has the reputation amongst fishers of being a worthy opponent; it comes out of the water snapping and thrashing, with razor-sharp teeth and spiny fins. The fish's neck must be broken before the hook can be safely removed, as it delivers a blood-thinning toxin with its bite. During my 2011 fieldwork, the fishers I spoke to on the boats offloading at Miller's Point slipway on the Cape Peninsula told me stories of wounds bleeding for a day or more if not treated properly. To treat such a wound, fishers have traditionally cut open the fish's eye and used that viscous to wash out the wound. Ideally, it must be the eye of the fish that bit you, or it won't work as quickly. Fresh handline snoek usually lack one eye anyway; fishers find that a thumb in the eye is the easiest grip with which to break the fish's neck, which must be done very quickly.

"Slaan my dood met 'n pap snoek" is an old saying, in the colorful Afrikaans of the Cape. It literally translates as "knock me dead with a mushy snoek" and is an expression that means "that's astonishing." It derives its meaning from the tendency of snoek flesh to turn soft, and thus be a very ineffectual weapon. This is a significant feature of Cape snoek in that it determines how it is handled and viewed. As soon as a snoek is dead, the fisher must work hard to prevent its flesh turning into an undesirable mush. The scientific explanation for this tendency is that it is caused by a myxopsorean parasite (Kudoa thyrsites); this parasite was first recorded in the Cape snoek but its presence has also been noted in barracouta and other species. However, it is widely believed that working on a metal surface, keeping the fish too long on the line, not breaking the neck properly, or even catching in the months with " $R$ " in their name, will result in "pap," or mushy flesh. So Cape snoek has two personalities: a ferocious opponent, and a finicky, fragile object that needs to be treated gently lest it become "pap."

Snoek has long been a vital marine staple in the human diet. In the late 1600s, when the Cape was a Dutch-controlled supply station along the route from Europe to Asia, the plentiful snoek was integral to the provisioning of passing ships. The skills that the large Malay slave population in the Cape held regarding preserving fish in warm climates helped to make "ingelegte vis," or preserved/pickled fish, an important, reliable, and plentiful food for the journey onwards, either to the east or home to Europe (Davidson and Jaine 2006:730). Its abundance also meant that snoek became a staple in the diet of colonists, sailors, and slaves whose resident populations steadily grew once settlement was made. It is still called by the Dutch name for it, which derives from "zeesnoek," or sea pike. Pike was a favored domestic fish for the Dutch, and perhaps this is one of the reasons why snoek in particular was so popular in the Cape.

It is well known that the success of the Dutch East India Company refreshment station in the Cape was an important factor in their expansive economic exploits (Wilmot 1869:21). It can be argued that the snoek they took onto their ships as rations played a minor part in the success of their sea journeys. It played an important role in the daily economic life of the colony and was provided, along with mutton, as a cheap staple to slaves and servants. Excavations at Barack Street, considered a typical dwelling, reveal that the household servants ate mainly snoek, with the bones of other species contributing an insignificant amount (Hall et al. 1990:78).

Van Sittert (2001:8) notes how stockpiling dried snoek and keeping chickens were strategies to guard against hunger during lean times along the west coast, up into the $20^{\text {th }}$ century. When large schools of snoek are on the move, and accessible to fishers, it is said that the snoek are running. Although unpredictable, these snoek runs were relied on as important events for fishing communities and others along the west coast and Cape peninsula. Photos in the AG Photographic Collection in the Cape Archives in Capetown, taken by Ludvig Jindra, show St. Helena Bay's fishing beach in full swing during a run in 1973. The amount of fish is remarkable, as is the number of people unloading the fish, processing it, buying it, or just observing the rush of activity. The number of tents shown in these photos suggests that people came to camp out for the harvest-like event: next to them were countless lines of drying snoek, stretching down the beach. We know a successful snoek run meant a significant cash injection, and greater food security for a local community. The abundance of snoek, and its preservation (a finicky job) over long distances, meant that it was a cheap and plentiful food for the Cape's poorer people. As Isaacs (2013) shows, in the supply chain of the Ocean View fishing community in the western Cape of South Africa, snoek still remains a low-cost source of protein for many of the city's low-income communities

Snoek has connotations that associate the acts of catching and eating it with a particular race, which is not unusual in South Africa, still laboring under the legacy of apartheid. It is especially closely associated with the Cape's so-called "coloured" population. Note that the phrase "coloured" is an accepted term in South Africa which refers to the population of historically "mixed-race," largely Afrikaans-speaking inhabitants of the Cape, the descendants of whom today refer to themselves as coloured in a manner that evokes sociocultural boundaries as well as racial ones. The majority of Cape Town's fishermen, past and present, have been coloured men, as were cart merchants, whereas the fish processors have traditionally been coloured women. Scott (1951) gives us figures for the inshore fisheries of South Africa, focusing on the western Cape: in 1948, $4.7 \mathrm{~m}$ tonnes 
were canned, one-fifth of which went soft and was "sold at low prices to Cape Coloureds" (1951:145). That means that in 1948 almost $1 \mathrm{~m}$ tonnes of "pap" snoek was sold to the Cape's coloured population. This was a large amount of snoek to be sold to a targeted population. It would be interesting to know whether Scott is referring to the Cape as a province, or a city, but unfortunately he does not provide that specific detail.

Many documents in the Cape Archives discuss issues regarding snoek. Pages are filled with efforts trying to understand it, whether its erratic movements beneath the waves or its tendency to go "pap." It lives in faded handwriting on old paper, files bound together by disintegrating ties. It is a creature that is economically important, but problematizes its own status as a valuable commodity by going bad; much of the documentation deals with it as rotten or "pap," as an embarrassment to South African trade or the product of a noxious process. In the lean times of the Second World War, the Cape's abundance of snoek, coupled with South Africa's distance from the epicentre of the war and the low cost of production here, caught the eye of the British government who were trying to feed not only their troops but a beleaguered nation at home. However, although millions of cans of snoek were imported to the UK, the canning was badly done. According to Scott (1951:144), there were a number of reasons for this. The canneries were far from the fishing grounds; the catch per unit of effort was too high to put in more, shorter trips; and snoek must be frozen or salted as soon as it is dead, which was expensive to do in those days. Hence, the vast majority of Britons rejected the fish, even in the years of wartime deprivation. After it became clear that the British citizenry would not eat snoek, even after suggestions such as boiling it in brandy, it was sold at cost as cat food. It still has a terrible reputation amongst British visitors, who make up a large proportion of Cape Town's tourists. Another factor that counts against it as a gourmet dish is the presence of large, densely packed bones. In an online piece about snoek featured by Showcook, a number of Cape Town's top chefs are interviewed about why so little is seen of it on the more expensive menus. The general agreement among the chefs seems to be that because of the bones, they cannot serve the neat fillets of deboned fish that their customers expect. The bones and body shape of the snoek means that only experienced "vlekkers," or flayers, can fillet the fish; years of experience is needed to get proper fillets from the fish and not to deconstruct it into chunks. As one chef says in the piece, he only puts snoek on the menu either flaked or in a mousse. Another chef claims that he doesn't serve it because "white people don't eat it."

Yet, despite the embarrassment it may have ever caused in South Africa's trade with other countries, snoek nonetheless has a place as a topic in the media. In the National Film Archives of South Africa, there are two newsreel items that feature the beginning of the snoek runs in Cape Town, one dated from 1922, and another from 1968. Today, there are many blogs on the internet and clips on YouTube that feature a snoek run or the catch of a particularly fearsome-looking specimen. Not only has it remained a feature of the Cape, but also a feature of the Cape's representation by others. In 1938, the United Tobacco Company of South Africa issued 100 cigarette cards featuring artwork depicting typical scenes of South Africa. The "snoekers," or snoek boats, of Cape Town harbor made the grade. Its close associations with snoek conferred upon Cape Town the moniker "Snoektown." "Snoektown" was even the call sign for Cape Town in the early days of South African Airways. From the 1950s to the early 1970s, Springbok Radio broadcast a show called "Snoektown Calling", announced by the blowing of a dried kelp horn called the "snoekhorn." Snoekhorns were heard on the streets of Cape Town well into the $20^{\text {th }}$ century as fish merchants sold their wares from horse-drawn carts.

Bickford-Smith et al. have this to say about the radio station's use of the "snoekhorn:" "Cape Town's fish horns, whose raucous sound the white middle class had fought against for so long, were incorporated into the 'respectable' folk culture of the nation through Cecil Wightman's radio programme" (1999:67). What helped this incorporation along was the fish horn's later honor of being used to signal tries or victories for the western province rugby team's home games, which allows for comparison with the much-debated vuvuzela of soccer's 2010 World Cup fame. The name "Snoektown" still lives on, with references littering the internet as markers toward posts or articles that are either tongue-in-cheek or nostalgic. The name is often used in online news media to refer to Cape Town in a jocular manner that either aims to caricature Cape Town and the sea-obsessed Capetonians, or to evoke nostalgia for its colorful people and seaside living.

There are a number of blogs and forums on the internet where writers explain snoek to a variety of imagined audiences. It is an interesting array of opinions that enact both the snoek and the act of eating it as a cultural experience for which one must do the legwork. The act of finding snoek to buy is described by one observer, Ken Liffiton, as a quintessential Capetonian activity, even elevating it to slightly mythological standards: "Even after it is caught, the snoek is an elusive creature, and only a fool would dare tread into a supermarket or other organized store in search of snoek.... the real snoek hunters take to the streets." Not only is the fish judged in the practice of finding or choosing it, but the "hunter" is also. The late local chef Lannice Snyman (1979) describes the act of selecting snoek: "It's easy to tell the novice from the expert snoekselector. The former gingerly points out his pick from a safe distance; the expert knows what a fine specimen feels like, prodding gently until 'his' fish feels just right, grabbing it fearlessly by the tail." 
While the consumer watches and judges, he or she is also watched; indeed, as I have observed for myself on many occasions at formal and informal fish markets, the novice buyer is often vied over by the merchants, as they see the inexperienced as an opportunity to make extra money or offload less-than-premium product. This speaks not only to the cultural associations of snoek being central to the Capetonian experience and, thus, to the tourist experience, but also to the political economy that governs the catch and sale of it (also see Isaacs 2013).

It is often claimed that "no fish is more traditional to the Cape" and that it is "the best known and most versatile Cape fish" (van Wyk and Barton 2008). It is a traditional meal during Easter, a bigger event than Christmas for many communities, where fish, and especially "kerrievis" or curried fish, is the main item on the menu. Many articles by South Africans, particularly Capetonians, feature snoek as the classic Cape "braai," the South African, originally Afrikaans, word for barbecue, fish that must be tried. For those authors not living at "home," the quest to find a fresh snoek to "braai" is part of the joy of eating it again after months of pining. That way, you get to drive from the city to the harbors, asking people for "inside info," choosing the fish, and bartering. So snoek is also living imagination; it is a shorthand that summons, to memory and imagination, glittering seas, seagulls, sunshine, harbors, colorful boats, even more colorful conversation, fishers, fleckers and merchants, coastal drives, finding the fish, not finding the fish, preparing it, "braaing," finding it "pap," eating it with friends and family. When people reminisce about eating snoek, it is not only the particular taste of snoek that they speak about, but it is also these kinds of experiences-the ones that shape, in the memory and in the moment, a Cape Town that is held together by a strand of snoek. If you have tasted snoek before, the representation of the snoek, as something craved again, enacts a relation to Cape Town that could be read as nostalgic belonging; if you have never eaten snoek before, it is the experience that will allow you a deeper relation with many levels of the "real Cape Town:" scenery, wildlife, nature, people, and food.

The snoek multiple, then, is an unpredictable yet fierce commodity that requires certain social interactions for it to live up to its reputation. For Thyrsites atun to be Cape snoek, it must be encountered as the Cape snoek, fought for and caught in its waters, by people who "know" it; eaten or prepared by those who crave it specifically because it has significance in the iconography of the Cape. It is involved in a range of practices; for Mol (2002:44), a requisite of being. By situating the snoek multiple in the complex of its associations, by seeing it as "a convergence of complex and intricate relations between the versions thereof" (Mol and Law 2008:65), we can see the work that these relations do to allow these versions to "hang together" (Mol 2002).
As with the Norwegian salmon that Lien and Law (2011) speak of, the Cape snoek and the marine environment are performed together, as in the sketches of hunting and seeking it that I offer above. What would happen if the snoek were to be separated from the Cape's marine ecosystems? The luxury South African supermarket, Woolworths, has recently been selling New Zealand barracouta as "lightly smoked snoek." I asked the same fishers who told me stories of snoek bites about whether they think this is right. They all replied no, that even if the barracouta is a better product, it shouldn't be called snoek if it was not caught off the Cape's coasts (see also Isaacs 2013). I had first been alerted to the fact that Woolworths' snoek was barracouta by Mr. Emanuel dos Santos, who runs a locally famous fish shop in the city. He too considered such marketing as a sleight of hand; even though they are the same species, part of what makes snoek popular, besides the price, is its origins. Dependent on oceanographic, biological, and meteorological conditions, snoek may be a fierce, fat creature one year and a thin, slow creature the next, an unpredictability which characterizes much of its associations. It has "vitality," a phrase which Bennet explains as "the capacity of things...to not only impede or block the will and designs of humans, but also to act as...forces with trajectories, propensities, or tendencies of their own" (2009:viii). The snoek, and importantly, the human endeavor and cunning required to exploit this species, occupies a significant space in the imagining of the Cape. Like reports on the magnificent spectacle of the sardine run in the eastern Cape and Kwa-Zulu Natal, the snoek run is represented as a moment in which a communal spirit of place, in all its incarnations, is performed. It is an enduring image that collates a number of representations that are endemic to the Cape: the boats docking at the foot of the mountain; the colorful language of the fishers and merchants; the crowds waiting for their fish to either smoke or cook over an open fire; the tempestuous meteorological and marine environment.

\section{CONCLUSION}

Snoek shows us not only how publics create objects, but how objects feed back into the public's perceptions of themselves as individuals or collectives-how the process of creating objects and publics is mutual. This is an idea explored, in part, by novelist Imraan Coovaadia (2012), where the characters of his "taxi poets" create poems that are both their own creation and a product of the clamorous context of Cape Town. Furthermore, whereas these poems are articulated by the poets through the act of inscribing them on their landscape, the poets themselves find their own perspectives and lives changed by the act of articulation. By stating through his character's poetry that "the snoek has no teeth tiny enough by which to grasp its own condition," Coovaadia (2012) is collapsing the distinction between the subject that knows and the object that is known. This relates directly back to the ideas of Latour (1993), Mol (2002), Law and Mol (2008), and Lien and Law (2010). The 
act of constitution is mutual and it transgresses the boundary of the nature-culture or subject-object divide. By investigating the history of the snoek, and paying attention to how we construct the idea of it, we are also paying attention to how what we say about snoek says something about us.

Responses to this article can be read online at: http://www.ecologyandsociety.org/issues/responses. php/5866

\section{Acknowledgments:}

Support to the author by the South African Research Chairs Initiative of the Department of Science and Technology and the National Research Foundation, through the Research Chair in Marine Ecology and Fisheries, as well as the SeaChange Fund, is gratefully acknowledged. I would also like to thank Dr. Lesley Green and Dr. Astrid Jarre for their comments on early drafts, as well as the other fellow authors in this issue who contributed to my thinking through their participation in our themed session at the World Economic History Congress, Stellenbosch, June 2012. Thank you to Dr. Cecile Reed, Department of Biological Sciences, UCT, for assistance with names and taxonomic affiliation of snoek parasites. Special thanks to Dr. Rosemary Ommer and Dr. Barbara Paterson for their enthusiastic and supportive roles in bringing this paper to publication.

\section{LITERATURE CITED}

Bennet, J. 2009. Vibrant matter: apolitical ecology of things. Duke University Press, Durham, North Carolina, USA.

Bickford-Smith, V., E. van Heyningen, and N. Worden. 1999. Cape Town in the $20^{\text {th }}$ century. David Phillips, Cape Town, South Africa.

Coovadia, I. 2012. The institute of taxi poetry. Umuzi, Cape Town, South Africa.

Davidson, A., and T. Jain. 2006. The Oxford companion to food. $2^{\text {nd }}$ edition, Oxford University Press, Oxford, UK.

Hall, M., D. Halkett, J. Klose, G. Ritchie, and C. Poggenpoel. 1990. The Barrack Street well: images of a Cape Town household in the nineteenth century. The South African Archaeological Bulletin 45(152). http://dx.doi.org/10.2307/3887966

Isaacs, M. 2013. Small-scale fisheries governance and understanding the snoek (Thyrsites atun) supply chain in the Ocean View fishing community, Western Cape, South Africa. Ecology and Society 18(4): 17. http://dx.doi.org/10.5751/ ES-05863-180417
Latour, B. 1993. We have never been modern. Harvard University Press, Boston, Massachusetts, USA.

Law, J., and A. Mol. 2008. The actor enacted: the cumbrian sheep in 2001. Pages 57-77 in C. Knappett, and L. Malafouris, editors. Material agency: towards a non-anthropocentric approach. Springer, New York, New York, USA. http://dx. doi.org/10.1007/978-0-387-74711-8_4

Lien, M. E, and J. Law. 2011. 'Emergent aliens': on salmon, nature, and their enactment. Ethnos: Journal of Anthropology 76(1):65-87 http://dx.doi.org/10.1080/00141844.2010.549946

Mol, A. 2002. The body multiple. Duke University Press. Durham, North Carolina, USA.

Scott, P. 1951. Inshore fisheries of South Africa. Economic Geography. 27(2). University of Cape Town, Cape Town, South Africa. http://dx.doi.org/10.2307/141174

Snyman, L. 1979. Free from the sea. Lannice Snyman, Hout Bay, South Africa.

van Sittert, L. 2001 'To live this poor life': remembering the Hottentots Huisie squatter fishery, Cape Town, c.1934c.1965. Social History 26(1):1-21. http://dx.doi. org/10.1080/03071020010004390

Van Wyk, M., and P. Barton. 2007. Traditional South African cooking. Struik, Cape Town, South Africa.

Wilmot, A. 1869. History of the Colony of the Cape of Good Hope from its discovery to the year 1819. Longmans, Green, Reader and Dyer, London, UK. 